\title{
The zooplankton of the shallow lakes of the semi-arid region of southern South America
}

\author{
Santiago Andrés Echaniz ${ }^{*}$ and Alicia María Vignatti \\ Facultad de Ciencias Exactas y Naturales, Universidad Nacional de La Pampa, Avenida Uruguay 151, 6300 Santa Rosa, \\ La Pampa, Argentina
}

Received: 19 April 2017; Accepted: 4 September 2017

\begin{abstract}
The southern region of South America is arid and semi-arid, with an east-west gradient of precipitation. Most of its aquatic ecosystems are temporary lakes, with large variations in level and salinity. Although some ecological aspects of these lakes have been studied, the information on the relations between zooplankton and water chemistry, predation, effects of human activities, and the trophic status is scarce and scattered. The objective of this study was to determine the zooplanktonic composition, density, and biomass and their relationships with environmental variables in lakes of different phytogeographic regions of this region (Argentinian central pampa), subjected to different anthropic influences. Samples were taken from ten lakes with a salinity gradient between 0.38 and $115.5 \mathrm{~g} \cdot \mathrm{L}^{-1}$. The chemical composition revealed a distinction between sodic-bicarbonated and sodic-chlorinated lakes. We recorded 19 crustaceans and 30 rotifers and found inverse relationships between the richness and density and salinity and concentrations of most ions. Bicarbonated lakes were subsaline and characterized by greater richness and density, caused by rotifers. The most frequent species were Brachionus caudatus and Keratella tropica, and the crustaceans Bosmina huaronensis and Microcyclops anceps. The sodic-chlorinated lakes had lower richness and densities, and with distinguishable hyposaline and mesosaline populations with a predominance of neotropical endemic crustaceans, such as Moina eugeniae and Boeckella poopoensis, and hypersaline lakes with a predominance of Artemia permisilis. The biomass did not differ, but lakes with introduced fish fauna (subsaline and hyposaline) had smaller zooplankton, indicating the importance of the top down-effect in the zooplankton community structure.
\end{abstract}

Keywords: zooplankton / Argentinian central pampa / Daphnia menucoensis / Boeckella poopoensis / Artemia persimilis

\section{Introduction}

The composition and density of zooplankton of the epicontinental aquatic ecosystems are controlled by biotic and abiotic variables (D'Ambrosio et al., 2016). Among the biotic factors, two prominent ones are the availability of food resources and predation (Khan et al., 2003; Chang et al., 2004; Boveri and Quirós, 2007; Manca et al., 2008), and among the abiotic factors, the key factors include the size of the lake beds, environmental heterogeneity, temperature, $\mathrm{pH}$ (Hobæk et al., 2002; Hall and Burns, 2003), land use in the basins (Dodson et al., 2007), and salinity (Hammer, 1986; Williams, 1998; Ivanova and Kazantseva, 2006; D'Ambrosio et al., 2016). In particular, an increase in salinity increases the environmental

\footnotetext{
*Corresponding author:

santiagoechaniz@exactas.unlpam.edu.ar
}

stress (Herbst, 2001), and an inverse relationship exists between salinity and zooplankton richness and density (Hammer, 1986; Green, 1993; Greenwald and Hurlbert, 1993; Williams, 1998; Derry et al., 2003a; Hall and Burns, 2003; Nielsen et al., 2003; Ivanova and Kazantseva, 2006). However, the relationship between the presence and abundance of certain species and the ionic composition of water is not yet well described (Derry et al., 2003b). This is because, unlike seawater, which has a relatively constant salinity and a predominance of $\mathrm{NaCl}$, the amounts of the major ions and their proportions can vary among continental aquatic ecosystems (Kalff, 2002; Zalizniak et al., 2006).

These chemical variations led to the determination by Bos et al. (1996) that calcium and magnesium are key to the incidence of Artemia franciscana Kellogg, 1906, Moina hutchinsoni Brehm, 1937, Daphnia pulex Leydig, 1860, Ceriodaphnia laticauda P.E. Müller, 1867, and Simocephalus sp. Conversely, Derry et al. (2003b) verified the dominance of the rotifer Brachionus plicatilis O.F. Müller, 1786 and the 
Table 1. Denomination, geographic location, and main morphometric parameters of the lakes of the semi-arid southern South America (Argentinian central pampa) studied during 2007.



copepod Cletocamptus in waters dominated by $\mathrm{Cl}^{-}$, whereas Sarma et al. (2006) reported the prevalence of the copepods Leptodiaptomus sicilis Forbes, 1882 and Diaptomus nevadensis (Light, 1938) in waters dominated by $\mathrm{SO}_{4}{ }^{2-}$ and $\mathrm{CO}_{3}{ }^{2-}$. However, information on the relationships between some aspects of the epicontinental zooplankton (diversity, density and biomass) and the ionic composition of water in southern South America (Argentina) remains relatively scarce, largely because total salinity has been considered only generally, without discriminating its components (José De Paggi and Paggi, 1998; Modenutti et al., 1998; Locascio de Mitrovich et al., 2005; Echaniz et al., 2006, 2008, 2009, 2012; Vignatti et al., 2007, 2013; Battauz et al., 2013; D’Ambrosio et al., 2016). An additional complication is the frequent presence of endemic neotropical elements, particularly among cladocerans and copepods (Paggi, 1998; Menu-Marque et al., 2000; Adamowicz et al., 2004; Boxshall and Defaye, 2008; Forró et al., 2008), and little information exists that explains their patterns of temporal or biogeographic distribution.

The central region of southern South America is semi-arid, with a precipitation gradient ranging from about $800 \mathrm{~mm} \cdot \mathrm{yr}^{-1}$ to the east to about $300 \mathrm{~mm} \cdot \mathrm{yr}^{-1}$ to the west (Casagrande et al., 2006). This gradient results in marked phytogeographical differences (Cabrera, 1976) and, therefore, differences in the human activities that develop along it. The territory has numerous lakes, generally located in arheic basins, and these lakes, given the semi-arid nature of the region, are temporary and show large variations in level and salinity. To date, some limnological aspects of these lakes, including their zooplankton, have been studied (Echaniz et al., 2006, 2008, 2009, 2012, 2015; Vignatti et al., 2007, 2012, 2013, 2016; Echaniz and Vignatti, 2010, 2011, 2013; Del Ponti et al., 2015); however, these studies did not consider the relationships between geographic location, anthropic influences, and the characteristics of the zooplankton community. The information is also fragmented and dispersed, and particularly scarce in terms of the relationships of the chemical composition of water, predation, the effects of human activities, and the trophic state of the lakes to the composition and density of zooplankton. This lack of basic information may hinder comparisons that enable, among other aspects, the determination of the effects of climatic change or the elevation of salinity, which are both particularly important phenomena in the southern South America arid diagonal (D’Ambrosio et al., 2016).
The objectives of the present work were therefore to determine the main limnological parameters and the taxonomic composition, richness, density, and biomass of zooplankton in lakes located in the southern South America; to establish relationships between these features and to test the following hypotheses: (i) the ionic composition of the lake water influences the taxonomic composition of zooplankton; (ii) the zooplankton richness is related to salinity, the size of the lakes, and environmental heterogeneity; and (iii) the relative abundance of the different taxonomic groups is also controlled by biotic interactions, especially predation.

\section{Materials and methods}

\subsection{Study area}

We studied ten water bodies located in the three phytogeographic regions: the Pampa Plains, the Thorny Forest, and the Monte (Cabrera, 1976), which are each subjected to different anthropic influences (Tab. 1 and Fig. 1).

The Chadilauquen (Cha), Estancia Pey-Ma (EPM), and Estancia San José (ESJ) lakes are in the region of the Pampa Plains (Fig. 1). They are surrounded by fields dedicated to agriculture, mainly cereal and soybean crops. During the study, these lakes lacked fish fauna and aquatic vegetation.

The Ojo de agua Padre Buodo (OaPB) lies in the ecotone between the Pampa Plains and the Thorny Forest, Utracán (Ut) is in the center of the Thorny Forest, and El Carancho (EC) lies in the ecotone between this region and Monte (Cabrera, 1976). The lakes are surrounded by natural vegetation, and livestock is raised extensively in their basins. Ojo de agua Padre Buodo had no aquatic vegetation but contained a population of carp (Cyprinus carpio Linnaeus, 1758). Conversely, Ut and EC had no fish fauna but had variable coverings of the macrophyte Ruppia cirrhosa Petagna Grande.

All these lakes are temporary, shallow (Tab. 1), fed by rainfall and phreatic inputs (Dornes et al., 2016), and, as they are located in arheic basins, have water losses mainly caused by evaporation and percolation.

The Amarga Lake (LAm) is in the Monte region, surrounded by natural vegetation with a predominance of "jarillas" (Larrea sp.). This lake differs from the previous ones in that it is part of an exorheic basin, currently inactive, due to the construction of reservoirs in all the tributary rivers in the provinces of Mendoza 


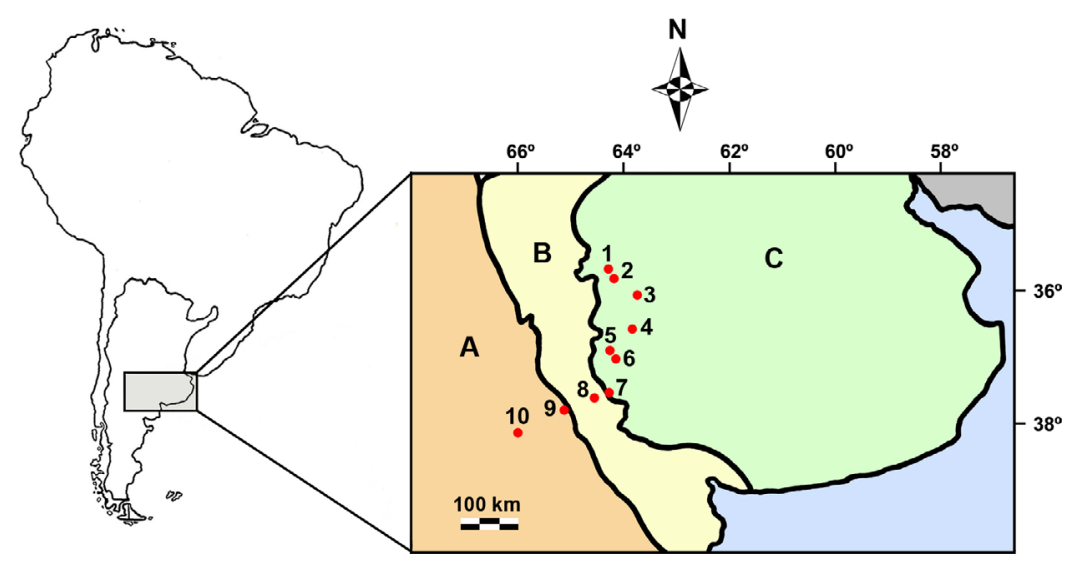

Fig. 1. Geographic locations of the ten lakes of the semi-arid southern South America (Argentinian central pampa) studied during 2007. 1: Cha; 2: EPM; 3: LAr; 4: ESJ; 5: DT; 6: BG; 7: OaPB; 8: Ut; 9: EC; 10: LAm. A: Phytogeographic region of the Monte; B: Thorny Forest; C: Pampa Plains.

and San Juan, northwest of the study area. This means that water only enters when the surplus of nival precipitation in the Andes forces an opening of the dam floodgates. In the past, the lake was permanent and had relatively low salinity but, at present, it is semi-permanent and its salinity is usually high. The region's reduced rainfall, which is around $350 \mathrm{~mm} \cdot \mathrm{yr}^{-1}$ (Casagrande et al., 2006), limits human activity to goat rearing.

The lakes La Arocena (LAr), Don Tomás (DT), and Bajo de Giuliani (BG) are located in the Pampa plains (Fig. 1), but they differ from the previously mentioned ones because they receive storm drains from the biggest cities of the region. In addition, $B G$ receives all of the sewage from a city with a population of about 100000 inhabitants. This means that, at present, all three lakes are permanent. All three have fish fauna, with a predominance of silversides (Odonthestes bonariensis Valenciennes, 1835).

\subsection{Field and laboratory work}

Sampling was carried out in the summer (January), autumn (April), winter (July), and spring (October) of 2007. Summer sampling in EC was done in early February, as the lake had been dry and was filled with torrential rain that occurred on January 26.

In situ determinations included water transparency (Secchi disk), $\mathrm{pH}$ (Corning ${ }^{\circledR}$ PS-15 pH meter), temperature, and dissolved oxygen concentration (Lutron DO 5510 digital oximeter). Water samples were taken at a depth of $0.5 \mathrm{~m}$ to determine salinity, ion content, suspended solids, nutrients, and phytoplankton chlorophyll- $a$ concentrations. Samples were kept in the dark and refrigerated until analysis.

At three sites located along the major axis of each lake, qualitative zooplankton samples were taken by vertical and horizontal trawls with a net $22 \mathrm{~cm}$ in diameter and with a $40 \mu \mathrm{m}$ mesh opening. Quantitative samples were collected with a $10 \mathrm{~L}$ capacity Schindler-Patalas trap, with a net with the same mesh opening. At each site, samples were taken at three depths and combined into one to obtain representative samples of the water column. Contractions and deformations were avoided by anesthetizing the organisms with $\mathrm{CO}_{2}$ and then fixing with $5 \%$ formalin. The samples were deposited in the National University of La Pampa collection.
The presence of fish was determined using trawls and traps, and collected specimens were also anesthetized by incorporation of $\mathrm{CO}_{2}$ into water and preserved in formaldehyde. When aquatic vegetation was present, its location and percentage of approximate coverage were visually determined and samples were taken for identification.

All applicable international, national, and institutional guidelines for the care and use of animals were followed.

The total dissolved solids (TDSs) were measured by a gravimetric method, by drying $50 \mathrm{~mL}$ of pre-filtered water at $104^{\circ} \mathrm{C}$ to a constant weight. The ionic content of the water was determined according to standardized routines (APHA, 1992).

The content of total suspended solids (TSSs), organic suspended solids (OSSs), and inorganic (ISSs) suspended solids was determined by filtration through Microclar FFG047WPH glass fiber filters that had been pre-washed and weighed, dried at $103-105^{\circ} \mathrm{C}$, and calcined at $550-600{ }^{\circ} \mathrm{C}$ (EPA, 1993). The total Kjeldahl nitrogen (TKN) was determined by the Kjeldahl method. Total phosphorus (TP) was determined spectrophotometrically following digestion of the sample with potassium persulfate in acid medium. The chlorophyll- $a$ concentration (Chl- $a$ ) was estimated by filtration through Microclar FFG047WPH glass fiber filters, extraction with aqueous acetone, and determination by spectrophotometry (Arar, 1997) with a Metrolab 1700 spectrophotometer.

Zooplankton density (ind. $\mathrm{L}^{-1}$ ) was determined by counts of micro- and macro-zooplankton (Kalff, 2002) in SedgwickRafter and Bogorov chambers, using an optical microscope at 40-100× magnification and a stereoscopic microscope at $20 \times$, respectively. The biomass $\left(\mu \mathrm{g} \cdot \mathrm{L}^{-1}\right)$ was determined based on at least 30 randomly obtained specimens per species, using a Leitz micrometric eyepiece. In the case of rotifers, the geometric shapes method was applied (Ruttner-Kolisko, 1977), and for crustaceans, dry weight/length regression relations were applied (Dumont et al., 1975; McCauley, 1984; Paggi, 1987).

\subsection{Quantitative analysis}

The classification system used for the lakes was the system based on salinity proposed by Hammer (1986). 
Table 2. Mean values and standard deviations of the main parameters determined in the ten lakes of the semi-arid southern South America during 2007.

\begin{tabular}{|c|c|c|c|c|c|}
\hline & Cha & EPM & LAr & ESJ & DT \\
\hline Temperature $\left({ }^{\circ} \mathrm{C}\right)$ & $17.18 \pm 7.18$ & $17.00 \pm 7.35$ & $17.58 \pm 7.43$ & $17.15 \pm 8.76$ & $16.95 \pm 9.00$ \\
\hline Transparency (m) & $0.81 \pm 0.38$ & $0.16 \pm 0.11$ & $0.42 \pm 0.38$ & $0.74 \pm 0.28$ & $0.14 \pm 0.04$ \\
\hline $\operatorname{TDSs}\left(\mathrm{g} \cdot \mathrm{L}^{-1}\right)$ & $25.27 \pm 1.50$ & $36.71 \pm 7.99$ & $0.38 \pm 0.08$ & $30.77 \pm 3.24$ & $0.95 \pm 0.23$ \\
\hline $\mathrm{pH}$ & $9.37 \pm 0.08$ & $9.44 \pm 0.16$ & $7.55 \pm 0.31$ & $9.43 \pm 0.10$ & $8.29 \pm 0.63$ \\
\hline $\mathrm{Cl}^{-}\left(\mathrm{mg} \cdot \mathrm{L}^{-1}\right)$ & $5941.75 \pm 2018.17$ & $8641.50 \pm 1901.90$ & $35.68 \pm 7.83$ & $10395.00 \pm 3969.94$ & $156.98 \pm 50.91$ \\
\hline $\mathrm{SO}_{4}{ }^{2-}\left(\mathrm{mg} \cdot \mathrm{L}^{-1}\right)$ & $3645.00 \pm 294.56$ & $3975.00 \pm 910.59$ & $88.50 \pm 134.76$ & $4150.00 \pm 1260.95$ & $266.25 \pm 212.66$ \\
\hline $\mathrm{Ca}^{2+}\left(\mathrm{mg} \cdot \mathrm{L}^{-1}\right)$ & $226.50 \pm 59.13$ & $276.70 \pm 58.18$ & $37.26 \pm 11.72$ & $528.00 \pm 117.26$ & $52.60 \pm 11.15$ \\
\hline $\mathrm{Mg}^{2+}\left(\mathrm{mg} \cdot \mathrm{L}^{-1}\right)$ & $82.35 \pm 21.21$ & $100.73 \pm 21.16$ & $13.58 \pm 4.26$ & $191.88 \pm 42.44$ & $19.18 \pm 4.06$ \\
\hline $\mathrm{K}^{+}\left(\mathrm{mg} \cdot \mathrm{L}^{-1}\right)$ & $208.50 \pm 39.37$ & $327.00 \pm 126.16$ & $1.90 \pm 0.42$ & $207.00 \pm 75.45$ & $5.68 \pm 4.22$ \\
\hline TSSs $\left(\mathrm{mg} \cdot \mathrm{L}^{-1}\right)$ & $38.56 \pm 44.81$ & $85.53 \pm 69.81$ & $32.30 \pm 27.68$ & $23.00 \pm 14.5$ & $65.91 \pm 17.28$ \\
\hline OSSs $\left(\mathrm{mg} \cdot \mathrm{L}^{-1}\right)$ & $9.80 \pm 8.21$ & $33.15 \pm 22.42$ & $27.50 \pm 25.48$ & $11.65 \pm 9.79$ & $59.92 \pm 14.01$ \\
\hline ISS $\left(\mathrm{mg} \cdot \mathrm{L}^{-1}\right)$ & $28.83 \pm 41.70$ & $52.38 \pm 48.48$ & $4.80 \pm 3.39$ & $11.36 \pm 11.1$ & $5.96 \pm 6.16$ \\
\hline & BG & $\mathrm{OaPB}$ & Ut & $\mathrm{EC}$ & LAm \\
\hline Temperature $\left({ }^{\circ} \mathrm{C}\right)$ & $17.43 \pm 9.09$ & $16.60 \pm 10.43$ & $16.73 \pm 7.97$ & $15.33 \pm 7.13$ & $14.58 \pm 7.99$ \\
\hline Transparency (m) & $0.16 \pm 0.05$ & $0.10 \pm 0.01$ & $1.05 \pm 0.39$ & $1.31 \pm 0.42$ & $1.54 \pm 0.15$ \\
\hline Dissolved oxygen $\left(\mathrm{mg} \cdot \mathrm{L}^{-1}\right)$ & $14.13 \pm 3.61$ & $11.50 \pm 5.59$ & $10.13 \pm 2.61$ & $9.58 \pm 0.69$ & $8.83 \pm 1.23$ \\
\hline TDSs $\left(g \cdot \mathrm{L}^{-1}\right)$ & $10.60 \pm 0.67$ & $0.51 \pm 0.02$ & $33.17 \pm 2.55$ & $11.60 \pm 4.28$ & $115.51 \pm 19.02$ \\
\hline $\mathrm{K}^{+}\left(\mathrm{mg} \cdot \mathrm{L}^{-1}\right)$ & $102.75 \pm 15.00$ & $2.15 \pm 0.47$ & $313.75 \pm 202.60$ & $129.50 \pm 71.45$ & $1020.25 \pm 580.11$ \\
\hline $\mathrm{Na}^{+}\left(\mathrm{mg} \cdot \mathrm{L}^{-1}\right)$ & $2915.00 \pm 518.05$ & $68.09 \pm 37.50$ & $9087.75 \pm 1559.95$ & $3574.75 \pm 1825.39$ & $30212.63 \pm 2726.21$ \\
\hline $\mathrm{TKN}\left(\mathrm{mg} \cdot \mathrm{L}^{-1}\right)$ & $19.69 \pm 3.25$ & $12.66 \pm 1.80$ & $15.94 \pm 5.83$ & $7.97 \pm 3.55$ & $25.32 \pm 12.29$ \\
\hline $\mathrm{TP}\left(\mathrm{mg} \cdot \mathrm{L}^{-1}\right)$ & $7.35 \pm 2.07$ & $4.07 \pm 0.36$ & $9.22 \pm 5.64$ & $6.10 \pm 2.00$ & $4.38 \pm 1.61$ \\
\hline Chlorophyll- $a\left(\mathrm{mg} \cdot \mathrm{m}^{-3}\right)$ & $204.02 \pm 27.45$ & $187.15 \pm 62.14$ & $1.43 \pm 1.39$ & $1.07 \pm 1.67$ & $1.65 \pm 1.16$ \\
\hline TSSs $\left(\mathrm{mg} \cdot \mathrm{L}^{-1}\right)$ & $127.98 \pm 53.10$ & $101.10 \pm 29.33$ & $8.80 \pm 4.33$ & $4.63 \pm 1.91$ & $10.82 \pm 6.20$ \\
\hline OSSs $\left(\mathrm{mg} \cdot \mathrm{L}^{-1}\right)$ & $92.58 \pm 21.00$ & $94.92 \pm 26.62$ & $4.46 \pm 1.59$ & $2.85 \pm 0.88$ & $3.88 \pm 2.01$ \\
\hline $\operatorname{ISS}\left(\mathrm{mg} \cdot \mathrm{L}^{-1}\right)$ & $35.16 \pm 40.04$ & $6.18 \pm 5.02$ & $4.34 \pm 3.52$ & $1.78 \pm 1.07$ & $6.94 \pm 5.44$ \\
\hline
\end{tabular}

The relationships between environmental factors and zooplankton attributes were determined by calculating Spearman's correlation coefficients, and the physical, chemical, and biological differences were determined using the KruskalWallis nonparametric analysis of variance (Sokal and Rohlf, 1995; Zar, 1996).

The groupings of lakes according to their environmental variables were made by performing Gower cluster analysis, and species associations were determined by cluster analysis based on the presence-absence Jaccard index.
The relationship between the abundance of the different taxa and their frequency of occurrence was analyzed using the nonparametric graphic test of Olmstead and Tukey (Sokal and Rohlf, 1995). Principal components analysis (PCA) was also performed, following a logarithmic transformation of the data (Pérez, 2004), including environmental variables and zooplankton richness, density, and biomass.

We used Infostat (Di Rienzo et al., 2010) and PAST (Hammer et al., 2001) software. 


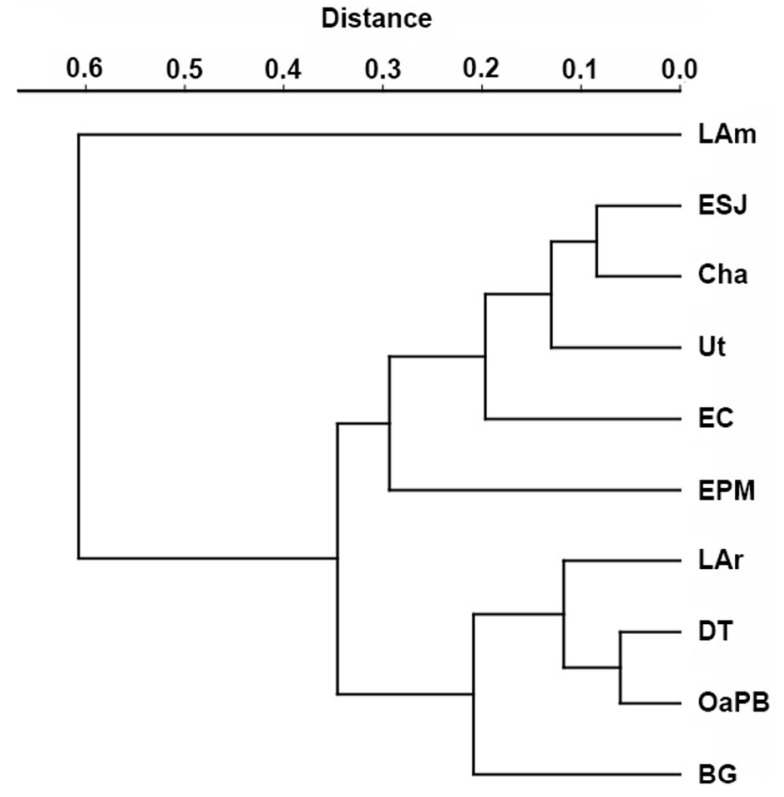

Fig. 2. Gower clustering of the ten lakes of the semi-arid southern South America, based on their chemical and physical parameters determined during 2007.

\section{Results}

\subsection{Environmental parameters}

The water temperature did not differ (Tab. 2) and followed a similar seasonal pattern in all water bodies. Both the maximum and the minimum temperatures (close to 29 and $4{ }^{\circ} \mathrm{C}$, respectively) were registered in OaPB.

The salinity differed $(H=37.61 ; p<0.0001)$ (Tab. 2), covering a wide range between a minimum of 0.32 and a maximum of $136.72 \mathrm{~g} \cdot \mathrm{L}^{-1}$ registered during the autumn in LAr and LAm, respectively. The EC showed a mean of around $11 \mathrm{~g} \cdot \mathrm{L}^{-1}$, but this increased from $5.7 \mathrm{~g} \cdot \mathrm{L}^{-1}$ immediately after filling (February) to $15.1 \mathrm{~g} \cdot \mathrm{L}^{-1}$ (October).

The $\mathrm{pH}$ also differed $(H=31.45 ; p=0.0003)$, and was greater than 9 in Cha, EPM, ESJ, BG, Ut, and EC, whereas in the other four lakes it did not exceed 8.5 (Tab. 2).

The concentrations of dissolved oxygen did not show any seasonal pattern and exceeded $7.0 \mathrm{mg} \cdot \mathrm{L}^{-1}$ (Tab. 2), with the exception of EPM, where smaller concentrations were registered (especially during the spring, when it decrease to $\left.2.4 \mathrm{mg} \cdot \mathrm{L}^{-1}\right)$.

Among cations, $\mathrm{Na}^{+}$was predominant in nine lakes, where it exceeded $80 \%$ of the total cations (Tab. 2). Its concentration differed $(H=36.15 ; p<0.0001)$ and fluctuated from a minimum of $24.5 \mathrm{mg} \cdot \mathrm{L}^{-1}$ in LAr (autumn) to a maximum of $32950.0 \mathrm{mg} \cdot \mathrm{L}^{-1}$ in LAm (autumn). The $\mathrm{Ca}^{2+}$ concentration also differed $(H=35.55 ; p<0.0001)$, but $\mathrm{Ca}^{2+}$ only represented a high percentage of the cations $(30.4 \%)$ in LAr (Tab. $2)$. The concentrations of $\mathrm{Mg}^{2+}$ and $\mathrm{K}^{+}$also differed $(H=35.36 ; p=0.0001$, and $H=34.15 ; p=0.0001$, respectively) but these cations had low percentages in all lakes (Tab. 2).

Among the anions, $\mathrm{Cl}^{-}$concentrations differed $(H=34.78$; $p=0.0001)$, ranging from $16.6 \mathrm{mg} \cdot \mathrm{L}^{-1}$ measured in $\mathrm{OaPB}$ to as much as $59953.0 \mathrm{mg} \cdot \mathrm{L}^{-1}$ recorded in LAm, both in winter (Tab. 2). It was the dominant anion in the highest-salinity lakes, while $\mathrm{HCO}_{3}{ }^{-}$dominated in the lower-salinity ones and represented $72.4 \%$ and $50.6 \%$ of the total of the anions, respectively, in LAr and DT (Tab. 2). $\mathrm{SO}_{4}{ }^{2-}$ followed in order of importance in most lakes, and concentrations close to $30 \%$ were registered in DT, OaPB, and Ut (Tab. 2). Variable concentrations of $\mathrm{CO}_{3}{ }^{2-}$ were only registered in the four mesosaline lakes and were undetectable in the rest (Tab. 2).

The TSS concentrations differed $(H=29.01 ; p=0.0006)$. OSSs were more abundant in LAr, DT, BG, and OaPB, where they exceeded $70 \%$ of the total (Tab. 2), while ISSs were more abundant in Cha, EPM, and LAm, where they exceeded $60 \%$. In Ut, EC, and ESJ, both fractions were registered in relatively similar proportions (Tab. 2).

The concentration of nutrients was high in the water of all the lakes. TP concentration did not differ $(H=12.53$; $p=0.1851)$, but that of TKN did differ $(H=26.27$; $p=0.0018$ ). The highest means of TP and TKN (close to 15 and $35 \mathrm{mg} \cdot \mathrm{L}^{-1}$, respectively) were registered in EPM, whereas the minimum TP concentration was found in $\mathrm{OaPB}$ and the minimum TKN concentration occurred in EC (Tab. 2).

The water transparency differed $(H=33.53 ; p=0.0001)$ and fluctuated over a wide range. It was reduced, almost always lower than $0.2 \mathrm{~m}$, in EPM, DT, BG, and OaPB, and higher, although variable, in Cha, ESJ, Ut, EC, and LAm (Tab. $2)$. The water transparency and OSSs $\left(r_{\mathrm{s}}=-0.91 ; p<0.0001\right)$ showed a correlation, although the reduced transparency in EPM was due to a large amount of ISSs $\left(r_{\mathrm{s}}=-0.79\right.$; $p<0.0001)$.

The concentrations of phytoplankton chlorophyll- $a$ differed $(H=33.33 ; p=0.0001)$. In DT, OaPB, and BG, the concentrations were higher than $140 \mathrm{mg} \cdot \mathrm{m}^{-3}$, while in Cha, LAr, ESJ, Ut, EC, and LAm, they never exceeded $55 \mathrm{mg} \cdot \mathrm{m}^{-3}$ (Tab. 2). The lakes registering the highest concentrations of chlorophyll- $a$ had a lower water transparency $\left(r_{\mathrm{S}}=-0.89\right.$; $p=0.0006$ ), except for EPM. Chlorophyll- $a$ and OSSs concentrations also showed a correlation $\left(r_{\mathrm{s}}=0.92 ; p\right.$ $<0.0001)$, whereas no correlations were noted with TP and TKN concentrations.

The environmental variables allowed the distinguishing of three groups of lakes: the first, comprising only LAm, had high concentrations of TDSs, ions, and nutrients, but a high water transparency; the second was a set of intermediate-salinity lakes, with the majority having relatively clear waters (ESJ, Cha, Ut, and EC) (EPM was also incorporated into this group, given its common chemical characteristics and despite its low transparency caused by ISSs); and the third group, comprising lakes of lower salinity (LAr, DT, OaPB, and BG), had low transparency water due to high amounts of chlorophyll- $a$ and OSSs (Fig. 2).

\subsection{Zooplankton}

The zooplankton richness was relatively high, since 49 taxa (19 crustaceans and 30 rotifers) were registered (Tab. 3). The richness and the concentration of TDSs were correlated $\left(r_{\mathrm{s}}=-0.88 ; p<0.0001\right)$, so that lakes with salinities of less than $1.2 \mathrm{~g} \cdot \mathrm{L}^{-1}$ (LAr, OaPB, and DT) contained between 19 and 25 taxa; those with salinities between 10 and $33 \mathrm{~g} \cdot \mathrm{L}^{-1}$ (Cha, ESJ, BG, Ut, and EC) contained 5-17 taxa; and those with salinity higher than $36 \mathrm{~g} \cdot \mathrm{L}^{-1}$ (EPM and LAm) contained only 2 
Table 3. Taxa registered during 2007 in ten lakes of the central semi-arid southern South America.






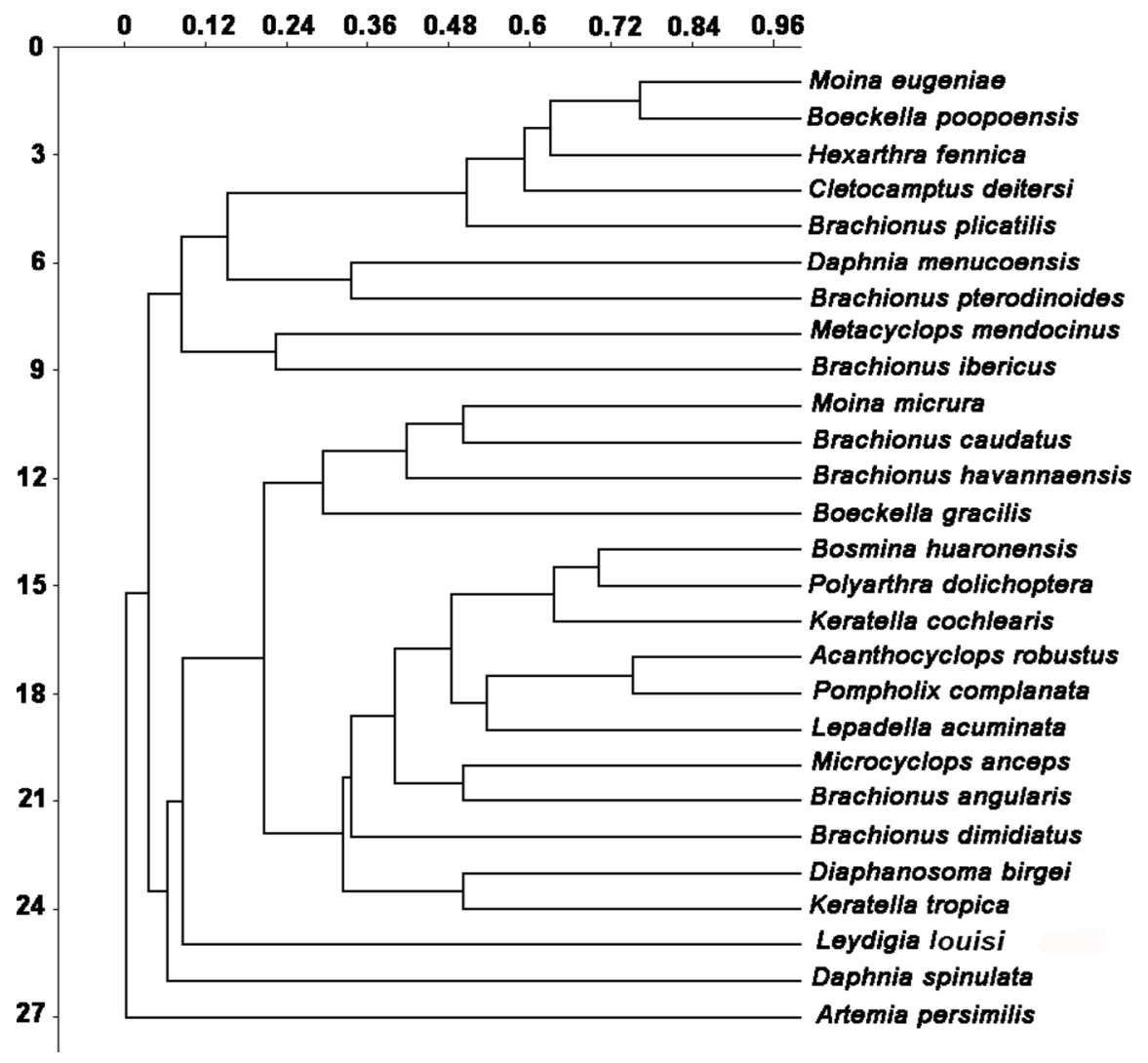

Fig. 3. Clustering analysis based on the presence-absence Jaccard index of the most representative zooplankton species recorded in the ten lakes of the semi-arid southern South America during 2007.

or 3 taxa. We also found correlation between richness and transparency $\left(r_{\mathrm{s}}=-0.40 ; p=0.0112\right)$ and richness and chlorophyll- $a\left(r_{\mathrm{s}}=0.46 ; p=0.0028\right)$, since the highest number of taxa was found in the LAr, OaPB, and DT lakes.

The genera Moina, Boeckella, and Brachionus predominated among the cladocerans, copepods, and rotifers, respectively. The species registered in most of the lakes were Boeckella poopoensis Marsh, 1906 (seven lakes), Cletocamptus deitersi (Richard, 1897) and B. plicatilis (six lakes), and Moina eugeniae Olivier, 1954 and Hexarthra fennica (Levander, 1892) (five lakes). Conversely, some taxa were found in a single environment, as in the case of the anostracan Artemia persimilis Piccinelli and Prosdocimi, 1968 or some rotifers of the Lecane, Trichocerca, Notholca, and Synchaeta genera (Tab. 3).

Three groups of species were determined (Fig. 3): the first group was found in the lakes with the highest salinity and consisted only of the anostracan $A$. persimilis; the second group was found in lakes of intermediate salinity and featured most frequently the crustaceans $M$. eugeniae and $B$. poopoensis and the rotifers $B$. plicatilis and H. fennica; and the third group, found in the environments with lower salinity, consisted especially of the cladocerans B. huaronensis, Moina micrura Kurz, 1874, and Daphnia spinulata Birabén, 1917, the copepod Boeckella gracilis (Daday, 1902), and the rotifers Brachionus caudatus Barrois and Daday, 1894, B. angularis Gosse, 1851, B. havanaensis Rousselet, 1913, Keratella tropica (Apstein, 1907), and K. cochlearis (Gosse, 1851).

The zooplankton densities of the lakes differed $(H=26.24$; $p=0.0019$ ) and ranged from 1.64 ind. $\mathrm{L}^{-1}$ in LAm to
20743 ind. $\mathrm{L}^{-1}$ in LAr (Fig. 4). The relatively high mean density (1328.55 ind $\cdot \mathrm{L}^{-1} \pm 2351.17$ ) found in $\mathrm{EC}$ was due to the high density found during the summer, immediately after filling; this subsequently diminished.

Correlations were found between total density and salinity $\left(r_{\mathrm{s}}=-0.62 ; p<0.0001\right)$, water transparency $\left(r_{\mathrm{s}}=-0.67 ; p\right.$ $<0.0001)$, and chlorophyll- $a$ concentration $\left(r_{\mathrm{s}}=0.66 ; p\right.$ $<0.0001)$. Although most lakes had their maximum peaks of abundance in the summer, no seasonal pattern of variation was detected.

The density of rotifers differed $(H=27.83 ; p=0.0010)$ and showed a negative influence of salinity $\left(r_{\mathrm{s}}=-0.74 ; p<0.0001\right)$, as rotifers were dominant in the subsaline lakes ( $\mathrm{LAr}, \mathrm{OaPB}$, and $\mathrm{BG})$, where they reached mean abundances of 19726.08 ind. $\cdot \mathrm{L}^{-1}( \pm 4303.62), 2150.33$ ind. $\cdot \mathrm{L}^{-1}( \pm 2143.38)$, and 1233.92 ind. $\cdot \mathrm{L}^{-1}$ ( \pm 2303.38$)$, respectively (Fig. 4$)$.

The density of crustaceans also differed $(H=19.91$; $p=0.0185)$ and was negatively affected by salinity $\left(r_{\mathrm{s}}=-0.41\right.$; $p=0.0081)$. Don Tomas reached a mean density of 2499.9 ind. $\cdot \mathrm{L}^{-1}$, more than double that of LAr and EC, the lakes that followed in descending order. The density of crustaceans also correlated with the water transparency $\left(r_{\mathrm{s}}=-0.56 ; p=0.0002\right)$ and chlorophyll- $a$ concentration $\left(r_{\mathrm{s}}=0.51 ; p=0.0009\right)$. With the exception of LAm, where the anostracans prevailed and represented almost $96 \%$ of the zooplankton, the copepods predominated in all lakes, while the cladocerans were not dominant in any of the lakes sampled (Fig. 4).

Among rotifers, $B$. plicatilis was the most frequent species (Fig. 5), despite not having high densities in any lake (except 


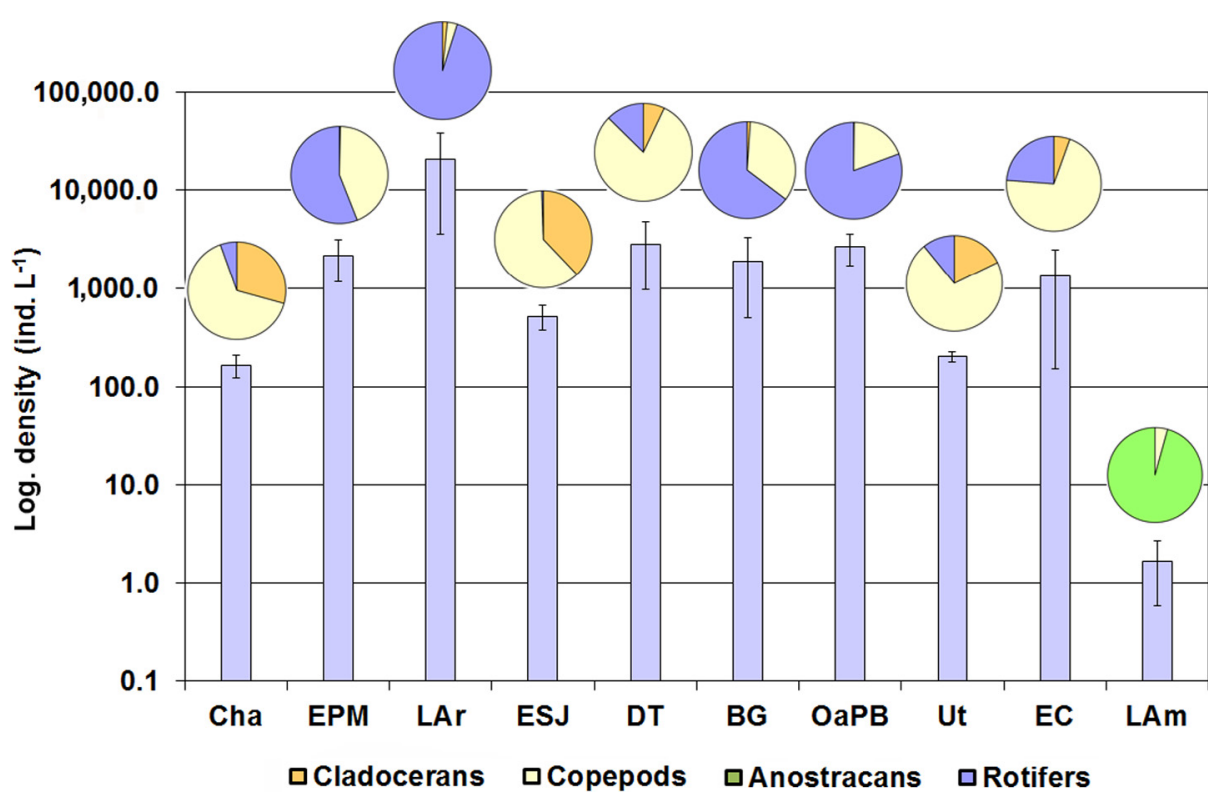

Fig. 4. Comparison of total mean zooplankton density (bars) in the ten lakes during 2007 and the relative contribution of each taxonomic group (circles). The $Y$ axis is in logarithmic scale and the bars indicate the standard deviations.

for EPM, where it exceeded $65 \%$ of the total). It was followed by $H$. fennica, which was very frequent in the lakes of higher salinities, in which it did not reach high densities (except in EC, where it represented $48.05 \%$ of the total mean abundance). Conversely, K. cochlearis, although relatively infrequent, was characterized by high abundances, such as in LAr, where it reached 65386.67 ind. $\mathrm{L}^{-1}$ in winter and accounted for $85 \%$ of the zooplankton community throughout the year. K. tropica also reached relatively high densities, since it reached 4326 ind. $\mathrm{L}^{-1}$ in autumn in $\mathrm{OaPB}$, exceeding $50 \%$ of the total abundance. The rest of the rotifers were characterized by their reduced frequencies, since they were generally found in a single water body at a low density (Fig. 5).

Among crustaceans, the most frequent and abundant species was the copepod B. poopoensis (Fig. 5), present in the highest-salinity lakes, such as EPM and ESJ, where it reached high mean annual densities of 617.14 ind. $\cdot \mathrm{L}^{-1}( \pm 362.57)$ and 202.63 ind. $\cdot \mathrm{L}^{-1}( \pm 158.5)$, respectively, and accounted for more than $45 \%$ of the total zooplankton community density. Cletocamptus deitersi was the next species in the order of frequencies, since it was recorded in six lakes, although always in low densities. Moina eugeniae was the most frequent cladoceran and reached mean annual densities that fluctuated between 6.59 ind. $\mathrm{L}^{-1}( \pm 11.62)$ in EPM and 197.75 ind. $\mathrm{L}^{-1}$ $( \pm 191.97)$ in ESJ; in those lakes, it exceeded $48 \%$ of the mean total abundance. Conversely, M. anceps (Richard, 1897) was the crustacean that reached the greatest density, such as in DT, where it reached a mean of 1124.1 ind. $\mathrm{L}^{-1}( \pm 1568.1)$ and represented $61 \%$ of the total density. It was followed by Bosmina huaronensis Delachaux, 1918, which had spring peaks of 1080.67 ind. $\mathrm{L}^{-1}$ and $771 \mathrm{ind} \cdot \mathrm{L}^{-1}$ in LAr and DT, respectively. The other taxa presented low frequencies and abundances, with some registered in only a single lake (Fig. 5).

Positive correlations were found between the density of some rotifers, such as B. plicatilis, and H. fennica, and the concentration of some ions, such as $\mathrm{SO}_{4}{ }^{2-}$ and $\mathrm{CO}_{3}{ }^{2-}$, while negative correlations were noted for others, including $B$. dimidiatus Bryce, 1931, B. angularis, K. tropica, and K. cochlearis and the concentrations of $\mathrm{Cl}^{-}, \mathrm{SO}_{4}{ }^{2-}, \mathrm{Na}^{+}, \mathrm{K}^{+}$, $\mathrm{Ca}^{2+}$ and $\mathrm{Mg}^{2+}$ (Tab. 4). In the case of crustaceans, positive correlations were found between the concentration of $\mathrm{Cl}^{-}$, $\mathrm{SO}_{4}{ }^{2-}, \mathrm{Na}^{+}, \mathrm{K}^{+}, \mathrm{Ca}^{2+}$, and $\mathrm{Mg}^{2+}$ and the densities of $M$. eugeniae, B. poopoensis, and A. persimilis, whereas the correlations were negative in the case of other species, such as B. huaronensis, M. anceps, and Metacyclops mendocinus (Wierzejski, 1892) (Tab. 4).

The zooplankton mean biomass was slightly higher for the lakes with greater salinity, but the differences were not significant. This parameter ranged from a minimum of $956.32 \mu \mathrm{g} \cdot \mathrm{L}^{-1}( \pm 327.53)$ in Ut to a maximum of $50678.18 \mu \mathrm{g} \cdot \mathrm{L}^{-1}( \pm 86818.13)$ in LAm (Fig. 6), and neither showed a pattern of seasonal variation. No correlations were found between zooplanktonic biomass and the main morphometric parameters of lakes, such as surface and maximum depth.

The rotifers contributed the highest biomass in LAr only, due to the predominance of $K$. cochlearis (Fig. 6). In the rest of the lakes, the greatest biomass was provided by the crustaceans. In LAm, almost all biomass was provided by the anostracan $A$. persimilis, while in EC, the cladocerans exceeded $85 \%$ of the total, due in particular to D. menucoensis. In the other lakes, copepods contributed the highest biomass (Fig. 6), with B. poopoensis in the highest-salinity lakes and the cyclopoids $M$. anceps and M. mendocinus in those with a lower concentration of salts.

The first two components of the PCA explained $68.9 \%$ of the total variance (Fig. 7). The test showed the influence of environmental stress on the structuring of the zooplankton community. Component 1 , which was positively correlated with chlorophyll- $a$ and OSS concentrations and negatively with salinity, showed that the favorable environmental conditions - represented by a greater food supply due to the high phytoplankton concentrations and lower osmotic stress due to the low salinity - favored a greater specific richness and total zooplankton density. However, these 
Table 4. Spearman's correlation coefficients between the density of the main zooplankton species and the water ions of the ten lakes. Values in bold are significant.

\begin{tabular}{|c|c|c|c|c|c|c|c|c|c|}
\hline & & $\mathrm{Cl}^{-}$ & $\mathrm{SO}_{4}^{2-}$ & $\mathrm{CO}_{3}{ }^{2-}$ & $\mathrm{HCO}_{3}^{-}$ & $\mathrm{Na}^{+}$ & $\mathrm{K}^{+}$ & $\mathrm{Ca}^{2+}$ & $\mathrm{Mg}^{2+}$ \\
\hline Artemia persimilis & $p$ & 0.0006 & 0.0032 & 0.1625 & 0.6212 & 0.0006 & 0.0011 & 0.0006 & 0.0006 \\
\hline Moina eugeniae & $p$ & 0.0163 & 0.0002 & $<\mathbf{0 . 0 0 0 1}$ & 0.0323 & 0.0040 & 0.0068 & 0.0461 & 0.0461 \\
\hline Daphnia menucoensis & $r_{\mathrm{s}}$ & 0.13 & -0.01 & 0.08 & 0.33 & 0.08 & 0.001 & 0.08 & 0.08 \\
\hline Bosmina huaronensis & $p$ & 0.0001 & $<\mathbf{0 . 0 0 0 1}$ & 0.0343 & 0.0819 & 0.0002 & 0.0002 & $<\mathbf{0 . 0 0 0 1}$ & $<\mathbf{0 . 0 0 0 1}$ \\
\hline \multirow{2}{*}{ Boeckella poopoensis } & $r_{\mathrm{s}}$ & 0.56 & 0.56 & 0.62 & 0.49 & 0.55 & 0.53 & 0.39 & 0.39 \\
\hline & $p$ & 0.0002 & 0.0002 & $<\mathbf{0 . 0 0 0 1}$ & 0.0014 & 0.0002 & 0.0004 & 0.0119 & 0.0119 \\
\hline \multirow{2}{*}{ Microcyclops anceps } & $r_{\mathrm{s}}$ & -0.64 & -0.68 & -0.46 & $-\mathbf{0 . 3 7}$ & -0.67 & -0.67 & -0.68 & -0.66 \\
\hline & $p$ & $<\mathbf{0 . 0 0 0 1}$ & $<\mathbf{0 . 0 0 0 1}$ & 0.0030 & 0.0188 & $<\mathbf{0 . 0 0 0 1}$ & $<\mathbf{0 . 0 0 0 1}$ & $<\mathbf{0 . 0 0 0 1}$ & $<\mathbf{0 . 0 0 0 1}$ \\
\hline Brachionus plicatilis & $p$ & 0.0832 & 0.0052 & 0.0001 & 0.0113 & 0.0300 & 0.0153 & 0.7590 & 0.7290 \\
\hline \multirow{2}{*}{ B. dimidiatus } & $r_{\mathrm{s}}$ & -0.44 & -0.43 & -0.28 & -0.21 & -0.45 & $-\mathbf{0 . 3 8}$ & $-\mathbf{0 . 3 3}$ & $-\mathbf{0 . 3 2}$ \\
\hline & $p$ & 0.0043 & 0.0061 & 0.0768 & 0.1930 & 0.0033 & 0.0161 & 0.0363 & 0.0435 \\
\hline \multirow{2}{*}{ B. angularis } & $r_{\mathrm{s}}$ & -0.61 & -0.60 & -0.41 & -0.27 & -0.57 & -0.55 & -0.47 & -0.45 \\
\hline & $p$ & $<\mathbf{0 . 0 0 0 1}$ & $<0.0001$ & 0.0086 & 0.0922 & 0.0001 & 0.0003 & 0.0022 & 0.0037 \\
\hline \multirow{2}{*}{ Keratella tropica } & $r_{\mathrm{s}}$ & -0.48 & -0.49 & -0.28 & -0.32 & -0.47 & -0.47 & -0.46 & -0.45 \\
\hline & $p$ & 0.0017 & 0.0013 & 0.0768 & 0.0414 & 0.0021 & 0.0020 & 0.0030 & 0.0034 \\
\hline \multirow{2}{*}{ K. cochlearis } & $r_{\mathrm{s}}$ & -0.47 & -0.52 & -0.31 & -0.22 & -0.48 & -0.50 & -0.48 & -0.46 \\
\hline & $p$ & 0.0022 & 0.0006 & 0.0518 & 0.1708 & 0.0016 & 0.0011 & 0.0017 & 0.0025 \\
\hline \multirow{2}{*}{ Hexarthra fennica } & $r_{\mathrm{s}}$ & 0.18 & 0.38 & 0.58 & 0.31 & 0.24 & 0.21 & 0.24 & 0.24 \\
\hline & $p$ & 0.2789 & 0.0168 & 0.0001 & 0.0492 & 0.1314 & 0.1938 & 0.1401 & 0.1401 \\
\hline
\end{tabular}

conditions had no major influence on the biomass of the community since, in general, the higher densities recorded in lakes of lower salinity were due to the predominance of small zooplankton. Conversely, the PCA also indicated that other environmental factors, such as water temperature or the availability of dissolved oxygen, not have influence on zooplankton in the studied lakes.

Zooplankton sizes were variable and differed $(H=27.33$; $p=0.0012$ ) (Fig. 8). The mean zooplankton length was positively correlated with the total solids concentration $\left(r_{\mathrm{s}}=0.74 ; p<0.0001\right)$ and negatively with chlorophyll- $a$ $\left(r_{\mathrm{s}}=-0.70 ; p<0.0001\right)$, but the zooplankton of the lakes that contained fish fauna were smaller, ranging from $334.6 \mu \mathrm{m}$ $( \pm 73.0)$ in LAr to $569.4 \mu \mathrm{m}( \pm 354.6)$ in BG. In lakes where the presence of fish was not verified, the zooplankton sizes were larger, ranging from $690.1 \mu \mathrm{m}( \pm 100.3)$ in EPM to $2615.8 \mu \mathrm{m}$ $( \pm 1803.5)$ in LAm (Fig. 7).

\section{Discussion}

The studied lakes covered a very wide range of salinity and they showed a diverse anthropic influence. The predominance of $\mathrm{Na}^{+}$in all the studied lakes, and $\mathrm{Cl}^{-}$in seven of them, distances them from the global generalization made by Kalff (2002), who mentioned $\mathrm{Ca}^{2+}$ and $\mathrm{Mg}^{2+}$ as the dominant cations and $\mathrm{HCO}_{3}{ }^{-}$ and $\mathrm{SO}_{4}{ }^{2-}$ as the dominant anions in most of the world's inland waters. However, the $\mathrm{Na}^{+}$and $\mathrm{Cl}^{-}$domain is shared with many environments of the Chaco-Pampa plain (Drago and Quirós, 1996; Fernández Cirelli and Miretzky, 2004).

The concentrations of nutrients in water were high but comparable to those recorded in other parts of Argentina, such as some shallow lakes in the East of Pampa Plains (Quirós et al., 2002). The sediments of most of the studied lakes were dominated by sand (Echaniz and Vignatti, 2013), which has a reduced capacity for adsorbing phosphorus and nitrogen (Kapanen, 2008). Therefore, the frequent resuspensions of sediments caused by the wind, the contributions of wild animals, and anthropic activities and the processes of accumulation favored by the arheic character of the basins (Echaniz and Vignatti, 2013) could explain the high concentrations of nutrients found in the water of the lakes; these were higher than those indicated by Quirós et al. (2002) and Sosnovsky and Quirós (2006) as some of the highest registered in the literature.

\subsection{The zooplankton of the lakes of the semi-arid Central Pampa of Argentina}

The distribution of the species was relatively heterogeneous; indicating that, on the scale considered in this study, the structure of the faunas does not respond to a regional pattern. 

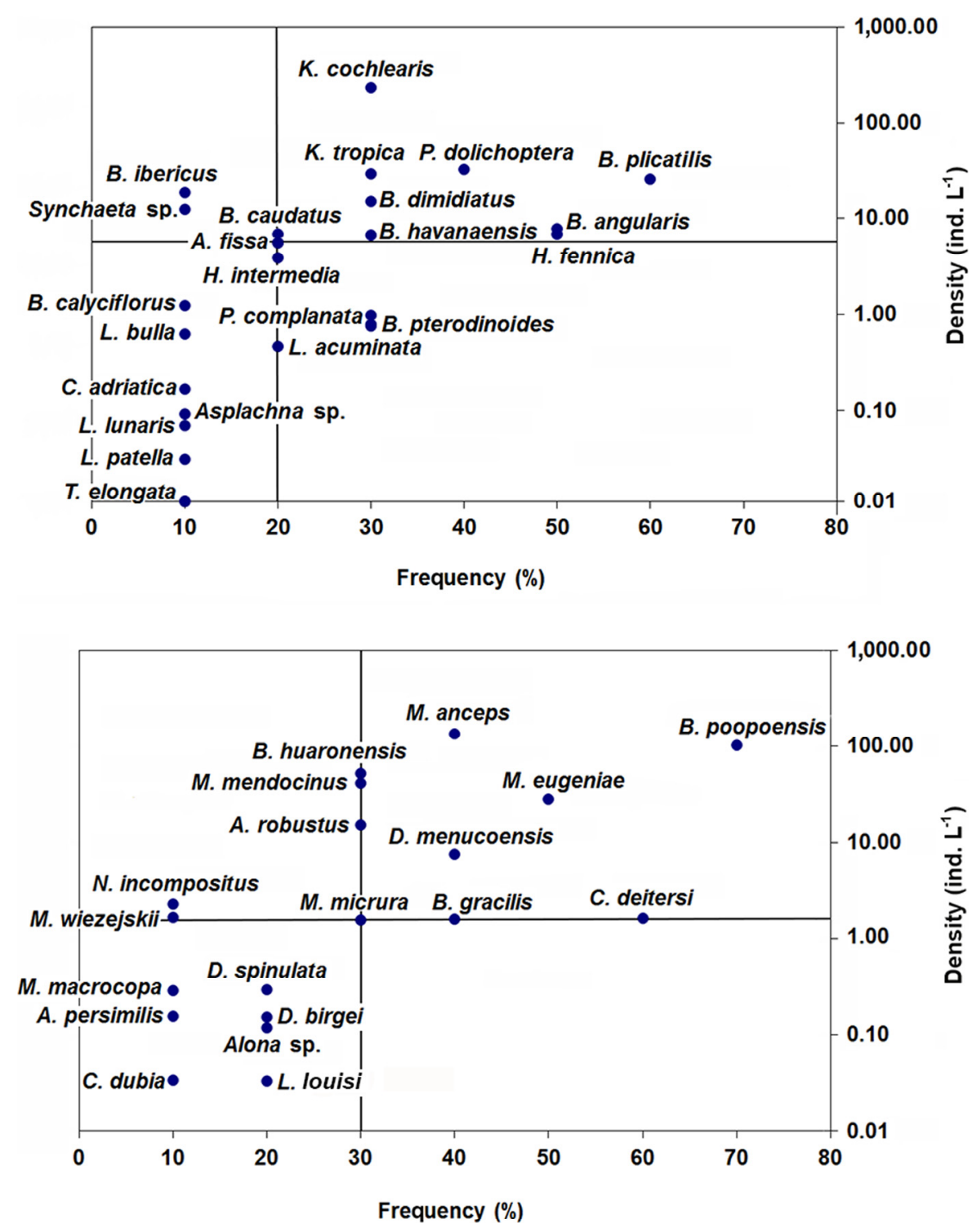

تิ

Fig. 5. Results of the nonparametric Olmstead and Tukey test showing the relationship between the density of the different taxa and their frequency of occurrence. Rotifers (above) and crustaceans (below).

The number of species showed an inverse relationship with the concentrations of TDSs and of the majority of the ions that comprise them. The greatest diversity was recorded in lakes with lower salinity, while in those that exceeded $20 \mathrm{~g} \cdot \mathrm{L}^{-1}$, the number of taxa was generally less than five or six. The importance of increasing salinity as a modulator of specific richness was evident in $\mathrm{EC}$, where the diversity was higher (10 taxa) after completion of the filling, when the salinity was close to $6 \mathrm{~g} \cdot \mathrm{L}^{-1}$, and was reduced (5-7 taxa) following the doubling or tripling of the salinity through the redissolution of salts accumulated in the sediments (Vignatti et al., 2012). This also provided information about the high diversity present in the egg bank of this lake, given the rapid recolonization by less tolerant species and its replacement by other halophiles at a later time (Vignatti et al., 2012).

The size of water bodies is a predictor of the number of zooplankton species since; in general, larger lakes may have a greater diversity of habitats, implying that they may be occupied by a larger number of species (Hobæk et al., 2002; Kalff, 2002). However, the studied lakes showed the opposite: the greater richness was registered in the smaller lakes, such as LAr, DT, and OaPB. All lakes showed little environmental heterogeneity, since they had relatively flat bottoms with homogeneous sediments and the majority lacked vegetation; however, the lakes mentioned are those that presented lower salinities and therefore lower environmental stress (Herbst, 2001).

The three subsaline lakes with a predominance of $\mathrm{HCO}_{3}{ }^{-}$ were those that were associated with the greatest richness and density, due especially to the rotifers. The zooplankton of these lakes was characterized by the cladocerans B. huaronensis and M. micrura, a very frequent association in shallow lakes and reservoirs in the central region of Argentina (Paggi, 1998). Other species were less frequent, such as Diaphanosoma birgei Korinek, 1981, which has been registered in La Pampa in very different environments, such as the deep and oligotrophic reservoir Casa de Piedra (Vignatti and Echaniz, 2008). The 


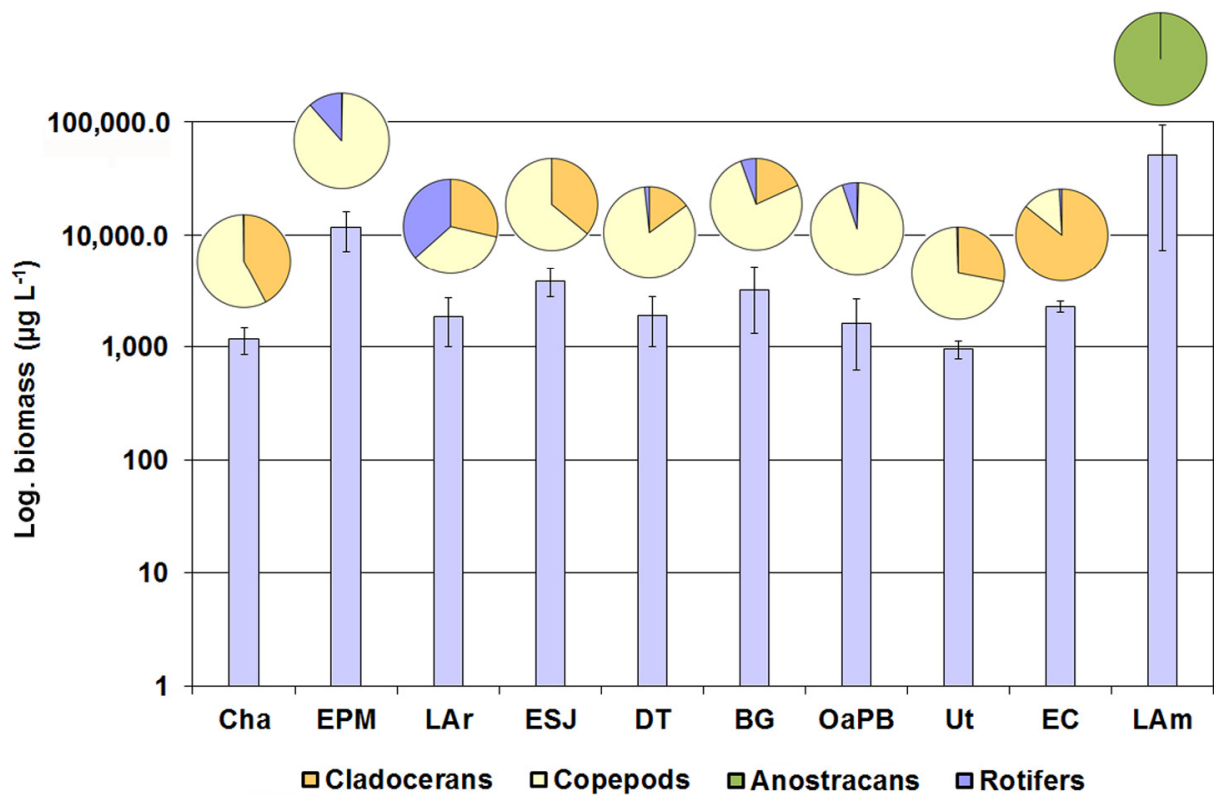

Fig. 6. Comparison of total mean zooplankton biomass (bars) in the ten lakes during 2007 and relative contribution of each taxonomic group (circles). The $Y$ axis is in logarithmic scale and the bars indicate the standard deviations.

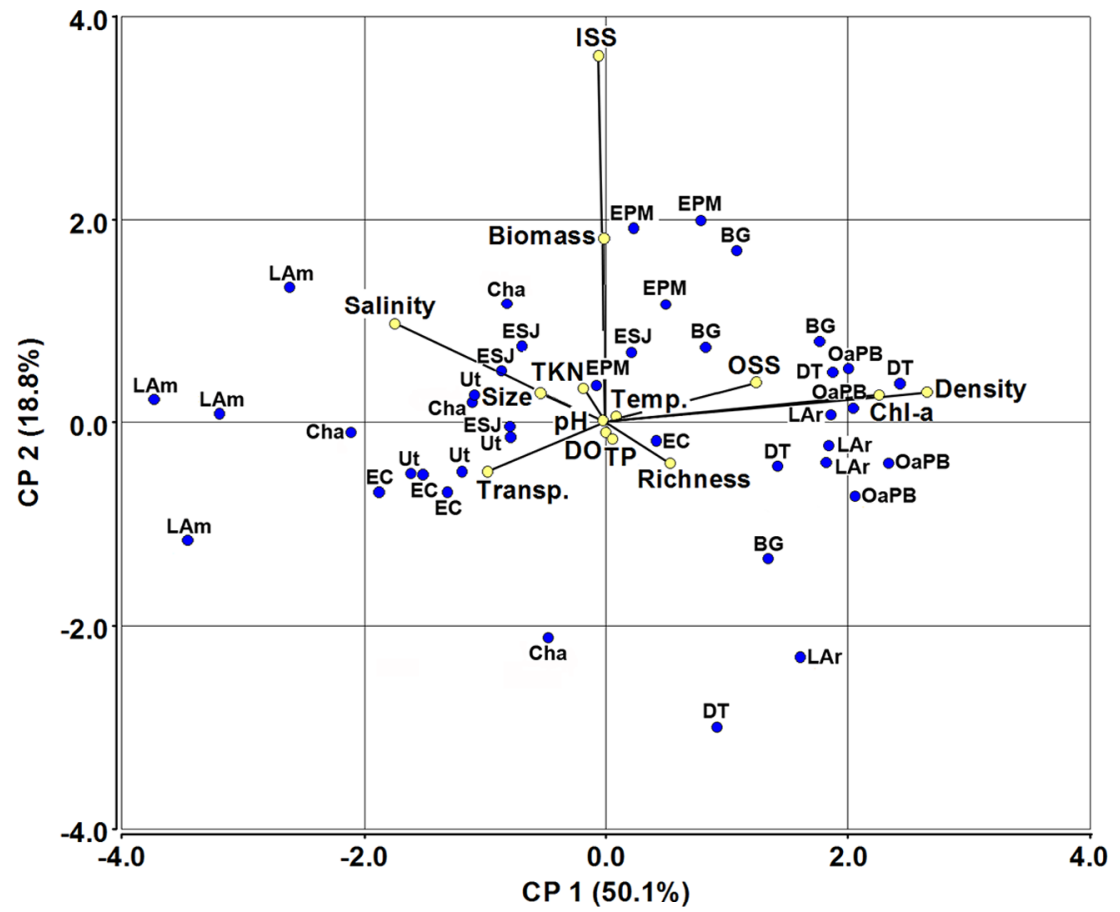

Fig. 7. Biplot showing the results of principal component analysis, including environmental variables and zooplankton richness, density, and biomass.

occurrence in plankton samples of Leydigia louisi Jenkin, 1934 could be accidental, as result of sediment resuspension, since it inhabits the upper layer of mud (Kotov, 2009). Daphnia spinulata was recorded on one occasion in DT, and its reduced density and later absence could be due to the predation exerted by the planktivorous fish (Scheffer, 1998; Quirós et al., 2002). These lakes were also characterized by cyclopoid copepods, such as M. anceps and Acanthocyclops robustus (G.O. Sars, 1863 ), and by the sporadic presence of some calanoids, such as Notodiaptomus incompositus (Brian, 1925) and B. gracilis, the latter being the most widely distributed boeckellid (MenuMarque et al., 2000).

The largest number of rotifers was found in these subsaline lakes, and most species had a cosmopolitan distribution, a 


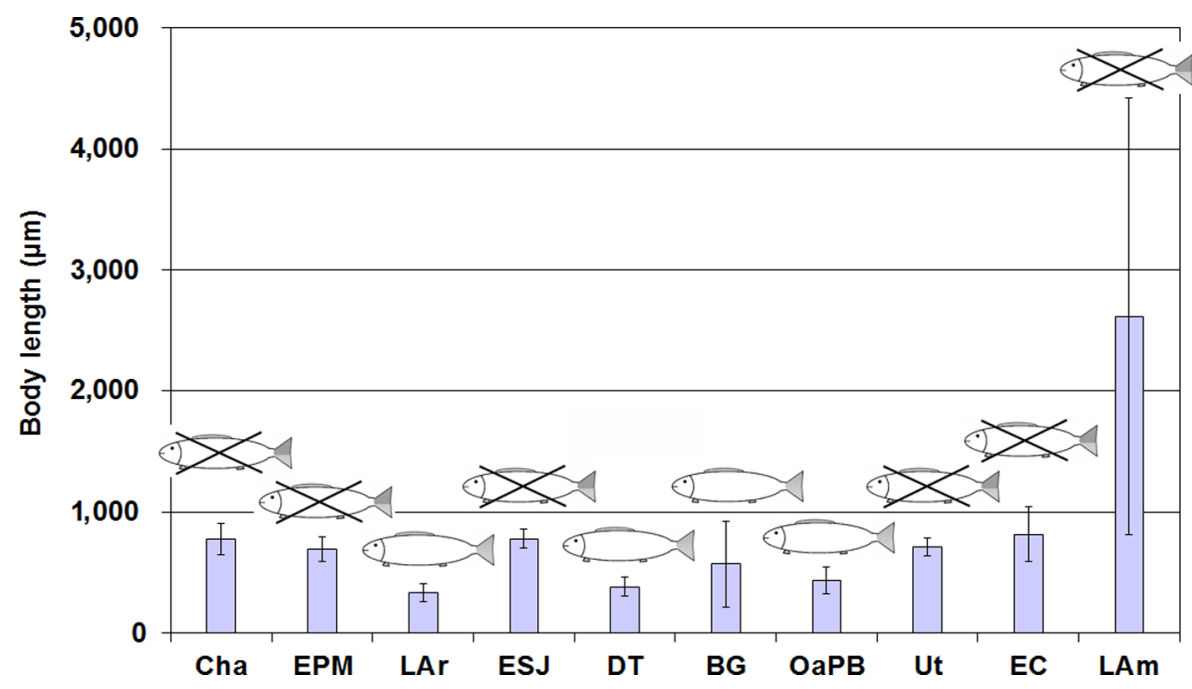

Fig. 8. Mean zooplankton lengths in the ten lakes with and without fish in the semi-arid southern South America during 2007. The bars indicate the standard deviations.

common situation for small organisms (Segers and De Smet, 2008). Among the rotifers, the genera Brachionus and Keratella were predominant, a feature in common with environments of similar salinities in the province of Buenos Aires (Ringuelet et al., 1967; Ardohain et al., 2005). Brachionus caudatus and $K$. tropica were the most frequent species and were related to the concentrations of $\mathrm{Ca}^{2+}, \mathrm{Mg}^{2+}$, and $\mathrm{HCO}_{3}{ }^{-}$. Fontaneto et al. (2006) indicated that the former is a haloxene species, typical of environments of less than $1 \mathrm{~g} \cdot \mathrm{L}^{-1}$, while $K$. tropica is relatively euryhaline. Brachionus dimidiatus is an infrequent cosmopolitan species adapted to saline waters (Pejler, 1995), although it probably has ample tolerance, since it was also registered in the three subsaline Pampean lakes. The two species of Keratella registered in La Pampa are euryhaline (Fontaneto et al., 2006), widely distributed in Argentina, and frequent in all types of environments, such as those found in the River Samborombón basin (Modenutti, 1998) and shallow lakes of Buenos Aires province (Ringuelet et al., 1967) and Patagonia (Modenutti et al., 1998). The predominance of rotifers resulted in a somewhat smaller biomass of zooplankton than in of the rest of the lakes studied in La Pampa, although the biomass was similar to that recorded in similar lakes in the province of Buenos Aires (Claps et al., 2004).

The hyposaline and mesosaline lakes with a predominance of $\mathrm{Cl}^{-}$and $\mathrm{Na}^{+}$showed a lower total zooplankton density than was found in the subsaline lakes, and the macrozooplankton was dominant, given the predominance of crustaceans. The ensemble of species differed from that of the subsaline lakes, indicating a replacement produced by increasing salinity and ion concentration. The crustaceans were predominantly endemic species of the Neotropical region and showed a close relation with $\mathrm{Cl}^{-}, \mathrm{SO}_{4}{ }^{2-}, \mathrm{Na}^{+}$, and $\mathrm{K}^{+}$levels. Among the cladocerans, $M$. eugeniae, a species restricted to saline waters of the central region of Argentina (Paggi, 1998), was the one that showed the greatest tolerance to salinity, since it was recorded in environments with values close to $35 \mathrm{~g} \cdot \mathrm{L}^{-1}$. Daphnia menucoensis Paggi, 1996 is also a very frequent species in saline environments of Patagonia and central
Argentina (Paggi, 1998; Vignatti and Echaniz, 1999; Adamowicz et al., 2004); however, its tolerance range appeared narrower than that of $M$. eugeniae, since the maximum salinity in which it was recorded was close to $30 \mathrm{~g} \cdot \mathrm{L}^{-1}$ and its density was very low on this occasion. Moina macrocopa (Straus, 1820) was found in EC; this species was introduced and registered in Argentina relatively recently and a recent introduction has been proposed in South America (Paggi, 1997). The species seems to have been distributed relatively quickly in the central part of the country, since it has been recorded in four other shallow Pampean lakes (Vignatti et al., 2013). The calanoid B. poopoensis was the most frequent and abundant crustacean. It is a halophilous species that has a very wide geographical distribution, from the north of Patagonia to the south of Peru (Menu-Marque et al., 2000; Vignatti et al., 2016). It showed a preference for the Pampean lakes containing $\mathrm{CO}_{3}{ }^{2-}$, which coincides with the predilection of other calanoids for waters where this ion is present (Derry et al., 2003b). This tolerant species was recorded in clear, turbid organic (BG) and inorganic turbid (EPM) environments and did not show the effects of fish predation, since the sizes recorded in lakes with or without fish fauna did not present significant differences (Vignatti et al., 2016). In these lakes, the harpacticoid $C$. deitersi was also very frequent, especially in lakes with high concentrations of $\mathrm{Ca}^{2+}$ and $\mathrm{Mg}^{2+}$, and its preference for environments dominated by $\mathrm{Cl}^{-}$coincided with that reported by Derry et al. (2003b) for Canadian lakes. Although it is considered a species of benthic habitat (RochaOlivares et al., 2001), its frequent presence in the zooplankton of the Pampean lakes could be due to the frequent disturbance produced by the wind, which would take the specimens up into the water column.

The richness of rotifers found in these environments was lower than that of the group of previous lakes, probably due to the limitation imposed by salinity, as field studies show that the number of species of rotifers decreases when salinity exceeds $2 \mathrm{~g} \cdot \mathrm{L}^{-1}$ (Green and Mengestou, 1991). Brachionus plicatilis and $H$. fennica dominated; both have a cosmopolitan distribution (Pejler, 1995) and are said to be strictly haline 
(i.e., not registered in environments of less than $1 \mathrm{~g} \cdot \mathrm{L}^{-1}$ ) (Fontaneto et al., 2006). In La Pampa, they were related to the presence of $\mathrm{Cl}^{-}$and $\mathrm{CO}_{3}{ }^{2-}$ in the water. It did not reach high densities, but $B$. plicatilis was the most frequent rotifer in hypo-mesosaline lakes, and its presence is a shared feature with similar Canadian water bodies (Derry et al., 2003a). Note, however, that a comparative analysis of mitochondrial DNA, 15 species are grouped under the name that constitutes the $B$. plicatilis species complex (Mills et al., 2016).

Hexarthra fennica belongs to a genus of halophilic species (Pejler, 1995), such as Hexarthra jenkinae (De Beauchamp 1932), that is dominant in saline lakes in Africa (Green, 1993) and North America (Jellison et al., 2001). Hexarthra fennica is found very frequently in Argentine saline waters (Modenutti, 1998) and has already been recorded in the semi-arid central pampa, sometimes as dominant, in lakes with salinities up to $40 \mathrm{~g} \cdot \mathrm{L}^{-1}$ and a dominance of $\mathrm{Cl}^{-}$(Echaniz et al., 2006). The presence of Brachionus ibericus Ciros-Perez, Gómez and Serra, 2001 in BG is of interest, as this haline species (Fontaneto et al., 2006), which adapts to lower salinity than $B$. plicatilis (Ciros-Pérez et al., 2001), had been cited for the first time on the American continent, based on the records of two intermediate mesosaline lakes with a dominance of $\mathrm{Cl}^{-}$and $\mathrm{Na}^{+}$in the semi-arid central pampa (Echaniz et al., 2006). Thus, B. ibericus, B. plicatilis, and B. rotundiformis are the three species of the $B$. plicatilis complex (Mills et al., 2016), registered currently in the center of Argentina (Ferrando and Claps, 2016). The biomass of these lakes was dominated by $B$. poopoensis, which accounted for $50 \%$ of the total, with the exception of EC, where D. menucoensis exceeded $75 \%$ of the total.

In LAm, a hypersaline lake with a dominance of $\mathrm{Cl}^{-}$and $\mathrm{Na}^{+}$, the osmotic stress means it can only be inhabited by a few tolerant species (Herbst, 2001). Only A. permisilis was recorded, accompanied on a single occasion by $B$. poopoensis. Artemia persimilis is a Neotropical endemic species and the only one of the genus that has been registered in the semi-arid central pampa. Artemia persimilis was the only species of the genus cited for the Argentine territory (Cohen, 1998), although A. franciscana, a species from North America, was subsequently registered in lakes of the north of the country, perhaps due to an anthropic introduction due to its economic value (Amat et al., 2004; Vikas et al., 2012) or to passive entry with migrations of birds from the northern hemisphere (Muñoz et al., 2013). One current debate is that distribution of $A$. persimilis could be diminishing due to the higher phenotypic plasticity attributed to its cogeneric species (Clegg and Gajardo, 2009; Vikas et al., 2012), although a possible limitation to the progression of $A$. franciscana to the south would be its lower tolerance to low temperatures (Browne and Wanigasekera, 2000; Amat et al., 2004; Vignatti et al., 2014); this could be modified in the case of temperature increases due to climate change (Dokulil, 2016).

The finding of $B$. poopoensis in this lake, on only one occasion and with an extremely reduced abundance, is interesting since this species had been recorded in Chile, Argentina, and Bolivia in salinities close to $90 \mathrm{~g} \cdot \mathrm{L}^{-1}$ (Bayly, 1993; De los Ríos, 2005; Locascio de Mitrovich et al., 2005). However, in the Argentinian central pampa, it showed a greater range of tolerance to salinity, since it was recorded at salinities of between $9 \mathrm{~g} \cdot \mathrm{L}^{-1}$ and more than $110 \mathrm{~g} \cdot \mathrm{L}^{-1}$.

\subsection{The effect of predation by fish on zooplankton in the lakes of the semi-arid southern region of South America}

The presence of predatory fish in some lakes enabled verification of the importance of the zooplankton in the determination of some characteristics of the lakes; especially the phytoplankton chlorophyll- $a$ concentrations and water transparency.

The zooplankton found in the subsaline lakes (LAr, DT, and $\mathrm{OaPB}$ ) and the hyposaline BG were smaller due to the predominance of rotifers and small crustaceans. This is a common situation in aquatic ecosystems, where relatively low salinity and permanence allow the development of fish fauna that may include zooplankton predators as silversides (Quirós et al., 2002; Reissig et al., 2006; Boveri and Quirós, 2007) and carps (Khan et al., 2003; Tátrai et al., 2003). The lakes mentioned can be classified as turbid (Scheffer, 1998), given their transparency of less than $0.5 \mathrm{~m}$, due to a great development of phytoplankton, which highlights the importance of predation in the structuring of the zooplankton community, and consequently of the conditions of the lake (Scheffer, 1998; Hobæk et al., 2002).

The zooplankton of the rest of the lakes was of greater size because its temporary nature and its high salinity create difficulties for the existence of fish populations, and consequently zooplankton grazing. This made the water transparency more than $0.7 \mathrm{~m}$, with low concentrations of chlorophyll- $a$ and suspended solids. The presence of $D$. menucoensis, one of the few halophilic species of the genus, in these lakes is worth noting (Echaniz et al., 2006). As with other species of Daphnia, its relatively large size and its high feeding rate (Muylaert et al., 2006) decrease phytoplankton amounts and increase water transparency. This highlights the importance of the zooplankton community in determining the characteristics of saline lakes that lack or have low densities of zooplanktivorous fish.

Acknowledgements. We thank the Facultad de Ciencias Exactas y Naturales, Universidad Nacional de La Pampa, for the partial financial support of the project; the Prato, Deanna and Fuentes families, owners of the establishments in which EPM, ESJ and EC, respectively, are located and the anonymous reviewers whose work improved this contribution.

\section{References}

Adamowicz S, Hebert P Marinone MC. 2004. Species diversity and endemism in the Daphnia of Argentina: a genetic investigation. Zool J Linn Soc: Lond 140: 171-205.

Amat F, Cohen R, Hontoria F Navarro J. 2004. Further evidence and characterization of Artemia franciscana (Kellog, 1906) populations in Argentina. J Biogeogr 31 (11): 1735-1749.

American Public Health Association (APHA). 1992. Standard methods for the examination of water and wastewater, 18th ed. Washington, DC.

Arar EJ. 1997. In vitro determination of chlorophylls a, b, c $+\mathrm{c}$ and pheopigments in marine and freshwater algae by visible spectrophotometry. Method 446.0. U.S. Environmental Protection Agency. 
Ardohain D, Benítez H, Claps MC, Gabellone N. 2005. Estructura y dinámica de rotíferos planctónicos en dos lagunas pampásicas: similitudes y diferencias. Biol Acuát 22: 7-18.

Battauz YS, Jose de Paggi SB, Paggi JC, Romano M, Barberis I. 2013. Zooplankton characterisation of Pampean saline shallow lakes, habitat of the Andean flamingoes. J Limnol 72: 531-542.

Bayly IAE. 1993. The fauna of athalassic saline waters in Australia and the Altiplano of South America: comparisons and historical perspectives. Hydrobiologia 267: 225-231.

Bos D, Cumming B, Watters C, Smol J. 1996. The relationship between zooplankton, conductivity and lake water ionic composition in 111 lakes from the Interior Plateau of British Columbia. Canada. Int J Salt Lake Res 5: 1-15.

Boveri M, Quirós R. 2007. Cascading trophic effects in pampean shallow lakes: results of a mesocosm experiment using two coexisting fish species with different feeding strategies. Hydrobiologia 584: 215-222.

Boxshall G, Defaye D. 2008. Global diversity of copepods (Crustacea: Copepoda) in freshwater. Hydrobiologia 595: 195-207.

Browne R, Wanigasekera G. 2000. Combined effects of salinity and temperature on survival and reproduction of five species of Artemia. J Exp Mar Biol Ecol 244: 29-44.

Cabrera A. 1976. Regiones fitogeográficas argentinas. Enciclopedia Argentina de agricultura y jardinería. Buenos Aires: Ed. Acme, $85 \mathrm{p}$.

Casagrande G, Vergara G, Bellini Y. 2006. Cartas agroclimáticas actuales de temperaturas, heladas y lluvias de la provincia de La Pampa (Argentina). Rev Fac Agronom UNLPam 17 (1/2): 15-22.

Chang K, Nagata T, Hanazato T. 2004. Direct and indirect impacts of predation by fish on the zooplankton community: an experimental analysis using tanks. Limnology 5: 121-124.

Ciros-Pérez J, Gómez A, Serra M. 2001. On the taxonomy of three sympatric sibling species Brachionus plicatilis (Rotifera) complex from Spain, with the description of B. ibericus n.sp. J Plankton Res 23: 1311-1328.

Claps M, Gabellone N, Benítez H. 2004. Zooplankton biomass in an eutrophic shallow lake (Buenos Aires, Argentina): spatio-temporal variations. Ann Limnol - Int J Limnol 40 (3): 201-210.

Clegg JS, Gajardo G. 2009. Two highly diverged New World Artemia species, A. franciscana and A. persimilis, from contrasting hypersaline habitats express a conserved stress protein complement. Comp Biochem Phys 153: 451-456.

Cohen G. 1998. Anostraca. In Coscarón S, Morrone JJ, eds. Biodiversidad de Artrópodos Argentinos. La Plata: Ediciones Sur, pp. 491-501.

D'Ambrosio DS, Claps MC, García A. 2016. Zooplankton diversity of a protected and vulnerable wetland system in southern South America (Llancanelo area, Argentina). Int Aquat Res 8: 65-80.

De los Ríos P. 2005. Richness and distribution of zooplanktonic crustacean species in Chilean altiplanic and southern Patagonia ponds. Pol J Environ Stud 14: 817-822.

Del Ponti O, Cabrera G, Vignatti A, Echaniz S. 2015. Dynamics of the limnological parameters and zooplankton of La Brava, a shallow lake of the Atuel-Salado-Chadileuvú-Curacó rivers system (La Pampa, Argentina). Appl Ecol Environ Sci 3 (6): 193-199.

Derry A, Hebert P, Prepas E. 2003a. Evolution of rotifers in saline and subsaline lakes: a molecular phylogenetic approach. Limnol Oceanogr 48 (2): 675-685.

Derry A, Prepas E, Hebert P. 2003b. A comparison of zooplankton communities in saline lakewater with variable anion composition. Hydrobiologia 505: 199-215.

Di Rienzo JA, Casanoves F, Balzarini MG, González L, Tablada MC, Robledo W. 2010. InfoStat (versión 2010). Córdoba: Grupo InfoStat, FCA, Universidad Nacional de Córdoba.
Dodson S, Everhart W, Jandl A, Krauskopf S. 2007. Effect of watershed land use and lake age on zooplankton species richness. Hydrobiologia 579: 393-399.

Dokulil M. 2016. Climate impacts on ecohydrological processes in aquatic systems. Ecohydrol Hydrobiol 16: 66-70.

Dornes P, Comas R, Cardín D, Pochetti R, Ianni J, Kruse E. 2016. Identificación y caracterización hidrológica de lagunas en el centroeste de la Provincia de La Pampa. In García R, Rocha V, Dornes P, eds. Relación Agua Subterránea-Superficial. IX Congreso Argentino de Hidrogeología - VII Seminario Hispano Latinoamericano de Hidrología Subterránea, Catamarca, pp. 213-220.

Drago E, Quirós R. 1996. The hydrochemistry of inland waters of Argentina; a review. Int J Salt Lake Res 4: 315-325.

Dumont H, van de Velde I, Dumont S. 1975. The dry weight estimate of biomass in a selection of Cladocera, Copepoda and Rotifera from the plankton, periphyton and benthos of continental waters. Oecologia 19: 75-97.

Echaniz S, Vignatti A. 2010. Diversity and changes in the horizontal distribution of crustaceans and rotifers in an episodic wetland of the central region of Argentina. Biota Neotrop 10 (3): 133-141.

Echaniz S, Vignatti A. 2011. Seasonal variation and influence of turbidity and salinity on the zooplankton of a saline lake in central Argentina. Lat Am J Aquat Res 39 (2): 306-315.

Echaniz S, Vignatti A. 2013. Trophic status of shallow lakes of La Pampa (Argentina) and its relation with the land use in the basin and nutrient internal load. J Environ Prot 4: 51-60.

Echaniz S, Vignatti A, José de Paggi S, Paggi J, Pilati A. 2006. Zooplankton seasonal abundance of South American saline shallow lakes. Int Rev Hydrobiol 91: 8-100.

Echaniz S, Vignatti A, Bunino P. 2008. El zooplancton de un lago somero hipereutrófico de la región central de Argentina. Cambios después de una década. Biota Neotrop 8 (4): 63-71.

Echaniz S, Vignatti A, Cabrera G. 2009. Características limnológicas de una laguna turbia orgánica de la provincia de La Pampa y variación estacional del zooplancton. Biol Acuát 26: 71-82.

Echaniz S, Vignatti A, Cabrera G, José de Paggi S. 2012. Zooplankton richness, abundance and biomass of two hypertrophic shallow lakes with different salinity. Biota Neotrop 12(2): 37-44.

Echaniz S, Cabrera G, Vignatti A. 2015. The ecology of the saline lakes in the semiarid Pampa central (Argentina): limnological characterization and zooplankton of Utracán. Adv Life Sci 5 (3): 64-72.

Environmental Protection Agency (EPA). 1993. ESS Method 340.2: total suspended solids, mass balance (dried at $103-105^{\circ} \mathrm{C}$ ) volatile suspended solids (ignited at $550{ }^{\circ} \mathrm{C}$ ), http://www.epa.gov/glnpo/ $1 \mathrm{mmb} / \mathrm{methods} / \mathrm{methd340.pdf}$ (accessed online: 2010/20/06).

Fernández Cirelli A, Miretzky P. 2004. Ionic relations: a tool for studying hydrogeochemical processes in Pampean shallow lakes (Buenos Aires, Argentina). Quatern Int 114: 113-121.

Ferrando N, Claps MC. 2016. A revised and updated checklist of Monogononta rotifers from Argentina. Check List 12 (4): 1-26.

Fontaneto D, De Smet W, Ricci C. 2006. Rotifers in saltwaters, reevaluation of an inconspicuos taxon. J Mar Biol Assoc UK 86: 623-656.

Forró L, Korovchinsky N, Kotov A, Petrusek A. 2008. Global diversity of cladocerans (Cladocera; Crustacea) in freshwater. Hydrobiologia 595: 177-184.

Green J. 1993. Zooplankton associations in East African Lakes spanning a wide salinity range. Hydrobiologia 267: 249-256.

Green J, Mengestou S. 1991. Specific diversity and community structure of Rotifera in a salinity series of Ethiopian inland waters. Hydrobiologia 209: 95-106. 
Greenwald G, Hurlbert S. 1993. Microcosm analysis of salinity effects on coastal lagoons plankton assemblages. Hydrobiologia 267: 307-335.

Hall C, Burns C. 2003. Responses of crustacean zooplankton to seasonal and tidal salinity changes in the coastal Lake Waihola, New Zealand. New Zeal J Mar Fresh 37: 31-43.

Hammer U. 1986. Saline lake ecosystems of the world. Dordrecht: Dr. W. Junk Publishers, $616 \mathrm{p}$.

Hammer Ø, Harper D, Ryan P. 2001. PAST: paleontological statistics software package for education and data analysis. Palaeontol Electron 4: 1-9.

Herbst D. 2001. Gradients of salinity stress, environmental stability and water chemistry as a templet for defining habitat types and physiological strategies in inland salt waters. Hydrobiologia 466: 209-219.

Hobæk A, Manca M, Andersen T. 2002. Factors influencing species richness in lacustrine zooplankton. Acta Oecol 23: 155-163.

Ivanova M, Kazantseva T. 2006. Effect of water $\mathrm{pH}$ and total dissolved solids on the species diversity of pelagic zooplankton in lakes: a statistical analysis. Russ J Ecol 37 (4): 264-270.

Jellison R, Adams H, Melack J. 2001. Reappearance of rotifers in hypersaline Mono Lake, California, during a period of rising. Lake levels and decreasing salinity. Hydrobiologia 466: 39-43.

José De Paggi S, Paggi J. 1998. Zooplancton de ambientes acuáticos con diferentes estados tróficos y salinidad. Neotropica 44(1): 95-106.

Kalff J. 2002. Limnology: inland water system. New Jersey: Prentice Hall, 592 p.

Kapanen G. 2008. Phosphorus fractionation in lake sediments. Eston $J$ Ecol 57 (4): 244-245.

Khan T, Wilson M, Khan M. 2003. Evidence for invasive carp mediated trophic cascade in shallow lakes of western Victoria, Australia. Hydrobiologia 506/509: 465-472.

Kotov A. 2009. A revision of Leydigia Kurz, 1875 (Anomopoda, Cladocera, Branchiopoda), and subgeneric differentiation within the genus. Zootaxa 2082: 1-84.

Locascio de Mitrovich C, Villagra de Gamundi A, Juárez J, Ceraolo M. 2005. Características limnológicas y zooplancton de cinco lagunas de la Puna Argentina. Ecol Bolivia 40(1): 10-24.

Manca M, Vijverberg J, Polishchuk L, Voronov D. 2008. Daphnia body size and population dynamics under predation by invertebrate and fish predators in Lago Maggiore: an approach based on contribution analysis. J Limnol 67 (1): 15-21.

McCauley E. 1984. The estimation of the abundance and biomass of zooplankton in samples. In Downing J, Rigler F, eds. A manual on methods for the assessment of secondary productivity in freshwaters. Oxford: Blackwell Scientific Publ., pp. 228-265.

Menu-Marque S, Morrone J, Locascio de Mitrovich C. 2000. Distributional patterns of the south american species of Boeckella (Copepoda: Centropagidae): a track analysis. J Crustacean Biol 20 (2): 262-272.

Mills S, Alcántara-Rodríguez A, Ciros-Pérez J, Gómez A, Hagiwara A, Hinson Galindo K, Jersabek C, Malekzadeh-Viayeh R, Leasi F, Lee J, Welch D, Papakostas S, Riss S, Segers H, Serra M, Shiel R, Smolak R, Snell T, Stelzer C, Tang C, Wallace R, Fontaneto D, Walsh E. 2016. Fifteen species in one: deciphering the Brachionus plicatilis species complex (Rotifera, Monogononta) through DNA taxonomy. Hydrobiologia 796(1): 39-58.

Modenutti B. 1998. Planktonic rotifers of Samborombón River Basin (Argentina). Hydrobiologia 387/388: 259-265.

Modenutti B, Balseiro E, Diéguez M, Queimaliños C, Albariño R. 1998. Heterogeneity of fresh-water Patagonia ecosystems. Ecol Aust 8: 155-165.
Muñoz J, Amat F, Green A, Figuerola J, Gómez A. 2013. Bird migratory flyways influence the phylogeography of the invasive brine shrimp Artemia franciscana in its native American range. PeerJ 1: e 200.

Muylaert K, Declerck S, Van Wichelen J, De Meester L, Vyverman W. 2006. An evaluation of the role of daphnids in controlling phytoplankton biomass in clear water versus turbid shallow lakes. Limnologica 36: 69-78.

Nielsen DL, Brock MA, Rees GN, Baldwin DS. 2003. Effects of increasing salinity on freshwater ecosystems in Australia. Aust $J$ Bot 51: 655-665.

Paggi JC. 1987. Limnological studies in Potter Peninsula, 25 de Mayo Island, South Shetland Islands: Biomass and spatial distribution of zooplankton. BIOMASS Scient Ser 7: 175-191.

Paggi JC. 1997. Moina macrocopa (Straus, 1820) (Branchiopoda, Anomopoda) in South America: Another case of species introduction? Crustaceana 70 (8): 886-892.

Paggi JC. 1998. Cladocera (Anomopoda y Ctenopoda). In Coscarón S, Morrone JJ, eds. Biodiversidad de Artrópodos Argentinos. La Plata: Ediciones Sur, pp. 507-518.

Pejler B. 1995. Relation to habitat in rotifers. Hydrobiologia 313/314: 267-278.

Pérez C. 2004. Técnicas de análisis multivariante de datos. Madrid: Pearson Educación, 672 p.

Quirós R, Rennella A, Boveri M, Rosso J, Sosnovsky A. 2002. Factores que afectan la estructura y el funcionamiento de las lagunas pampeanas. Ecol Aust 12: 175-185.

Reissig M, Trochine C, Queimaliños C, Balseiro E, Modenutti B. 2006. Impact of fish introduction on planktonic food webs in lakes of the Patagonian Plateau. Biol Conserv 132: 437-447.

Ringuelet R, Moreno I, Feldman E. 1967. El zooplancton de las lagunas de la Pampa Deprimida y otras aguas superficiales de la llanura bonaerense (Argentina). Physis 27: 187-200.

Rocha-Olivares A, Fleeger W, Foltz D. 2001. Decoupling of molecular and morphological evolution in deep lineages of a meiobenthic harpacticoid copepod. Mol Biol Evol 18(6): 1088-1102.

Ruttner-Kolisko A. 1977. Suggestions for biomass calculation of plankton rotifers. Arch Hydrobiol 8: 71-76.

Sarma S, Nandini S, Morales-Ventura J, Delgado-Martínez I, González-Valverde L. 2006. Effects of $\mathrm{NaCl}$ salinity on the population dynamics of freshwater zooplankton (rotifers and cladocerans). Aquat Ecol 40: 349-360.

Scheffer M. 1998. Ecology of shallow lakes. London: Chapman \& Hall, 358 p.

Segers H, De Smet W. 2008. Diversity and endemism in Rotifera: a review, and Keratella Bory de St Vincent. Biodivers Conserv 17: 303-316.

Sokal R, Rohlf F. 1995. Biometría. Principios y métodos estadísticos en la investigación biológica. Barcelona: Ed. Blume, 832 p.

Sosnovsky A, Quirós R. 2006. El estado trófico de pequeñas lagunas pampeanas, su relación con la hidrología y el uso de la tierra. Ecol Aust 16: 115-124.

Tátrai I, Kálmán M, Korponai J, Paulovits G, Pomogyi P, Héri J. 2003. Regulation of plankton by omnivore cyprinids in a shallow lake in the Kis-Balaton Reservoir System. Hydrobiologia 504: 241-250.

Vignatti A, Echaniz S. 1999. Presencia de Daphnia (Ctenodaphnia) menucoensis Paggi, 1996 en la provincia de La Pampa (Argentina). Rev Fac Agr UNLPam 10: 21-27.

Vignatti A, Echaniz S. 2008. El zooplancton del embalse Casa de Piedra (La Pampa, Argentina), distribución horizontal de abundancia y biomasa. BioScriba 1 (2): 46-59. 
Vignatti A, Echaniz S, Martín M. 2007. El zooplancton de lagos someros de diferente salinidad y estado trófico en la región semiárida pampeana (La Pampa, Argentina). Gayana 71 (1): 38-48.

Vignatti A, Paggi JC, Cabrera G, Echaniz S. 2012. Zooplankton diversity and its relationship with environmental changes after the filling of a temporary saline lake in the semi-arid region of $\mathrm{La}$ Pampa (Argentina). Lat Am J Aquat Res 40 (4): 1005-1016.

Vignatti A, Cabrera G, Echaniz S. 2013. Distribution and biological aspects of the introduced species Moina macrocopa (Straus, 1820) (Crustacea, Cladocera) in the semi-arid central region of Argentina. Biota Neotrop 13 (3): 86-92.

Vignatti A, Cabrera G, Pilati A, Echaniz S. 2014. Biology of Artemia persimilis Piccinelli and Prosdocimi, 1968 (Crustacea Anostraca) at the highest salinities reported for the species under natural conditions. Int J Artemia Biol 4 (1): 38-43.
Vignatti A, Cabrera G, Echaniz S. 2016. Biology of Boeckella poopoensis Marsh, 1906 (Copepoda, Calanoida) in natural conditions in temporary saline lakes of the central Argentina. Biota Neotrop 16(2): e20150063.

Vikas P, Sageshkumar N, Thomas P, Chakraborty K, Vijayan K. 2012. Aquaculture related invasion of the exotic Artemia franciscana and displacement of the autochthonous Artemia populations from the hypersaline habitats of India. Hydrobiologia 684: 129-142.

Williams WD. 1998. Salinity as a determinant of the structure of biological communities in salt lakes. Hydrobiologia 381: 191-201.

Zalizniak L, Kefford BJ, Nuggeggoda D. 2006. Is all salinity the same? I. The effect of ionic compositions on the salinity tolerance of five species of freshwater invertebrates. Mar Freshw Res 57: 75-82.

Zar JH. 1996. Biostatistical analysis. New Jersey: Prentice Hall, 663 p.

Cite this article as: Echaniz SA, Vignatti AM. 2017. The zooplankton of the shallow lakes of the semi-arid region of southern South America. Ann. Limnol. - Int. J. Lim. 53: 345-360 